AGNIESZKA MASNY

MONIKA MIESZCZAKOWSKA-FRĄC

ANITA KURAS

EDWARD ŻURAWICZ

MALGORZATA KORBIN

Instytut Ogrodnictwa, ul. Konstytucji 3 Maja 1/3, 96-100 Skierniewice

Kierownik Tematu: dr inż. Agnieszka Masny Instytut Ogrodnictwa, Zakład Hodowli Roślin Ogrodniczych,

ul. Pomologiczna 18, 96-100 Skierniewice, tel. 46 8345273; 501622880; e-mail: agnieszka.masny@inhort.pl

Prace zostaty wykonane $w$ ramach badań podstawowych na rzecz postępu biologicznego w produkcji roślinnej na podstawie decyzji Ministra Rolnictwa i Rozwoju Wsi nr HOR.hn.802.20.2018, Zadanie 76.

\title{
Badania nad możliwością zwiększenia zawartości składników bioaktywnych w owocach truskawki na drodze hybrydyzacji wewnątrz- i międzygatunkowej w obrębie rodzaju Fragaria
}

Studies on possibilities of increasing of bioactive compounds in strawberry fruits through intra- and interspecific hybridization within Fragaria genus

Słowa kluczowe: antocyjany, jakość owoców, kwas L-askorbinowy, polifenole, truskawka

Prace badawcze nad poszerzaniem zmienności genetycznej u truskawki obecnie ukierunkowane są głównie na poprawę zewnętrznej i wewnętrznej jakości owoców. Celem zadania jest określenie możliwości zwiększenia właściwości odżywczych i prozdrowotnych owoców truskawki poprzez zwiększenie w nich zawartości substancji bioaktywnych (przede wszystkim polifenoli, antocyjanów oraz kwasów organicznych) metodą hodowli konwencjonalnej w obrębie rodzaju Fragaria.

\section{CEL PODJETEGO TEMATU I PROWADZONYCH BADAŃ}

W 2018 r. realizowano trzy podzadania (tematy badawcze), których celem była: 
— ocena plonowania, jakości zewnętrznej i wewnętrznej owoców oraz podatności roślin na ważne gospodarczo choroby liści 180 mieszańców $\mathrm{F}_{1} \mathrm{z}$ rodzaju Fragaria, wyselekcjonowanych z populacji 12451 siewek i rozmnożonych w latach 2016-2017;

- szczegółowa analiza zawartości wybranych związków z grupy polifenoli w owocach 30 genotypów, dla których wyniki podstawowej analizy składu chemicznego potwierdziły najwyższą zawartość w owocach polifenoli i antocyjanów ogółem;

— zweryfikowanie statusu mieszańca dla 20 genotypów z rodzaju Fragaria, wyselekcjonowanych w latach 2017-2018 roku ze względu na dużą zawartość związków polifenolowych i antocyjanów w owocach.

\section{OPIS WYNIKÓW}

W temacie pierwszym wykonano ocenę fenotypową cech jakości owoców badanych 180 klonów (pomiar ich wielkości, a także ocena bonitacyjna wielkości, atrakcyjności, kształtu, barwy i połysku skórki oraz jędrności), która pozwoliła na wyodrębnienie genotypów o najwyższych wartościach wymienionych cech. Są to: T-201426-03 (rodowód 'Konfitura' × 'Grandarosa'), T-201428-02 ('Konfitura' $\times$ 'Elsanta'), T-201430-01 ('Madeleine' $\times$ 'Pink Rosa'), T-201436-04 i T-201436-05 ('Onda' × 'Grandarosa'), T-201444-01 i 201444-02 ('Ro×ana' × 'Pink Rosa'), T-201457-10 i T-201457-16 ('Grandarosa' × 'Elsanta'), T-201458-05 i T-201458-08 ('Pink Rosa' × 'Elsanta'), T-201462-02 (F. chiloensis Del Norte $\times$ 'Matis'), T-201501-03 ('Alba' × 'Grandarosa'), T-201511-01 ('Asia' × 'Panvik'), T-201512-05 ('Camarosa' × 'Panvik'), T-201514-01 i T-201514-08 ('Candiss' × 'Panvik') oraz T-201536-03 ('Clery' × 'Grandarosa'). Najwyższym poziomem kwasu askorbinowego w owocach (powyżej $75 \mathrm{mg} / 100 \mathrm{~g}$ ) odznaczały się klony: T-201488-12, T-201488-07, T-201488-13 i T-201488-06 ('Vibrant' $\times$ 'Matis'), T-201459-01 (F. chiloensis. Del Norte $\times$ 'Grandarosa'), T-201458-09 ('Pink Rosa' × 'Elsanta'), T-201457-11 ('Grandarosa' × 'Elsanta'), T-201436-01 ('Onda' × 'Grandarosa'), T-201536-16, T-201536-08 i T-201536-06 ('Clery' × 'Grandarosa'), T-201525-01 ('Cifrance' $\times$ 'Panvik'), T-201560-02 ('Onda' $\times$ 'Panvik') oraz T-201501-03 ('Alba' $\times$ 'Grandarosa'). Z kolei, najwyższym poziomem związków fenolowych (powyżej $180 \mathrm{mg} / 100 \mathrm{~g}$ ) w owocach wyróżniały się genotypy: T-201486-04 ('Camarosa' $\times$ 'Matis'), T-201458-01, T-201458-13, T-201458-07 i T-201458-06 ('Pink Rosa' × 'Elsanta'), T-201424-04 ('Honeoye' $\times$ 'Pink Rosa') oraz T-201442-01 ('Patty' $\times$ 'Elsanta'). Bardzo wysoką zawartość antocyjanów stwierdzono w owocach klonów T-201462-01 (F. chiloensis Del Norte $\times$ 'Matis'), T-201488-07 ('Vibrant' × 'Matis'), T-201437-01 ('Onda' × 'Pink Rosa'), T-201444-01 ('Roxana' × 'Pink Rosa'), T-201536-09 ('Clery' $\times$ 'Grandarosa'), T-201506-02 ('Alice' × 'Pink Rosa'), T-201508-01 ('Alice' × 'Matis'), T-201514-02 i T-201514-08 ('Candiss' × 'Panvik'), T-201512-03 ('Camarosa' × 'Panvik'), T-201513-03 ('Candiss' × 'Matis') oraz T-201560-11 ('Onda' × 'Panvik')

$\mathrm{W}$ temacie drugim wykazano, że badane klony różniły się profilem antocyjanów, jednak zawsze dominującym związkiem był glukozyd-3-pelargonidyny, którego udział procentowy mieścił się $\mathrm{w}$ przedziale $66,7 \%-91,1 \%$, następnym antocyjanem stanowiącym udział w przedziale $1,4 \%-25,3 \%$ był malonyloglikozyd-3-pelargonidyny. Pozostałe 
antocyjany: glukozyd-3-cyjanidyny, rutozyd-3-pelargonidyny i malonyloglukozyd-3cyjanidyny stanowily maksymalnie 13,2; 8,3 i 1,7\% wszystkich antocyjanów. Najwyższą zawartość tych składników stwierdzono w owocach pięciu genotypów: T-201437-01 ('Onda' × 'Pink Rosa') i T-201449-01 ('Sophie' × 'Matis') - 41 mg/100 g świeżej masy owoców; T-201442-01 ('Patty' × 'Elsanta') i T-201458-06 ('Pink Rosa' × 'Elsanta') - $47 \mathrm{mg} / 100 \mathrm{~g}$ oraz T-201488-07 ('Vibrant' × 'Matis') - $62 \mathrm{mg} / 100 \mathrm{~g}$. Owoce dwóch klonów: T-201436-02 ('Onda' × 'Grandarosa') i T-201458-01 ('Pink Rosa' $\times$ 'Elsanta') posiadały bardzo niski poziom antocyjanów w porównaniu z pozostałymi badanymi genotypami, odpowiednio $7 \mathrm{mg} / 100 \mathrm{~g}$ i $9 \mathrm{mg} / 100 \mathrm{~g}$.

Zawartość kwasu elagowego w owocach większości badanych klonów truskawki wynosiła od 30 do 40 g/100 g świeżej masy owoców. Najwyższą zawartość tego składnika stwierdzono w owocach klonów: T-201458-17 ('Pink Rosa' $\times$ 'Elsanta') $51 \mathrm{mg} / 100 \mathrm{~g}, \mathrm{~T}-201437-01$ ('Onda' × 'Pink Rosa') $-52 \mathrm{mg} / 100 \mathrm{~g}$ i T-201458-06 ('Pink Rosa' $\times$ 'Elsanta') $-58 \mathrm{mg} / 100 \mathrm{~g}$. Najniższą zawartość kwasu elagowego oznaczono w owocach genotypu T-201436-02 ('Onda' × 'Grandarosa') $-17 \mathrm{mg} / 100 \mathrm{~g}$.

$\mathrm{W}$ temacie trzecim przeprowadzono łącznie 1674 reakcje amplifikacji. W reakcji amplifikacji z 9 parami starterów (BFACT045, ARSFL009, ARSFL015, COBRA-R, EMFvi003, EMFv003, FAC001, FrH4177, FrH4163) uzyskano 468 amplikonów, z których $89 \%$ było polimorficznych. Długość amplikonów wahała się od 170 do 450 pz. Analizowane genotypy truskawki scharakteryzowano na podstawie 8-18 polimorficznych fragmentów DNA. Status mieszańca potwierdzono dla 19 z 20 testowanych. Określono również procentowy udział amplikonów pochodzących od formy matecznej, który wynosił od $100 \%$ do $18 \%$. Najwyższy udział fragmentów DNA charakterystycznych dla formy matecznej obserwowano na matrycy DNA wydzielonych z genotypów nr: 3, 6 ('Grandarosa' × 'Elsanta') oraz 10, 12 i 15 ('Pink Rosa' × 'Elsanta'), najniższy zaś dla mieszańców nr 13 i 14 ('Pink Rosa' × 'Elsanta').

\section{WNIOSKI}

1. Klony T-201436-05 ('Onda' $\times$ 'Grandarosa'), T-201444-01 ('Roxana' $\times$ 'Pink Rosa'), T-201457-16 ('Grandarosa' × 'Elsanta'), T-201458-05 ('Pink Rosa' $\times$ 'Elsanta'), T-201462-02 (F. chil. Del Norte $\times$ 'Matis'), T-201501-03 ('Alba' $\times$ 'Grandarosa'), T-201511-01 ('Asia' × 'Panvik'), T-201512-03 ('Camarosa' $\times$ 'Panvik'), T-201514-01 i T-201514-08 ('Candiss' × 'Panvik'), T-201536-03 i T-201536-15 ('Clery' × 'Grandarosa'), T-201537-01 ('Clery' × 'Matis') i T-201555-02 ('Marmolada' × 'Grandarosa'), ze względu na wysoką jakość owoców i odporność lub małą podatność na choroby liści, są genotypami perspektywicznymi do uprawy towarowej.

2. Owoce klonów T-201430-01 ('Madeleine' $\times$ 'Pink Rosa') i T-201444-01 ('Roxana' $\times$ 'Pink Rosa'), a także T-201424-04 ('Honeoye' × 'Pink Rosa'), T-201436-02 ('Onda' × 'Grandarosa'), T-201457-05 i T-201457-17 ('Grandarosa' × 'Elsanta'), T-201458-01 i T-201458-12 ('Pink Rosa' $\times$ 'Elsanta') oraz T-201536-03 ('Clery' × 'Grandarosa') i T-201560-02 ('Onda' × 'Panvik'), ze względu na wysoką zawartość takich 
związków bioaktywnych, jak: związki polifenolowe, antocyjany, a także kwas askorbinowy, są szczególne cenne dla diety człowieka.

3. Owoce klonów T-201437-01 ('Onda' × 'Pink Rosa') i T-201458-06 ('Pink Rosa' × 'Elsanta'), z uwagi na bardzo wysoką zawartość kwasu elagowego oraz związków z grupy antocyjanów, stanowią cenny składnik żywności funkcjonalnej.

4. Istnieje możliwość kontrolowanego zapylania genotypów w obrębie rodzaju Fragaria (status mieszańca pochodzącego z planowanego zapylenia uzyskało 19 z 20 testowanych mieszańców $\mathrm{F}_{1}$ ). 